\title{
Philippe Jaccottet. \\ A la lumière d'hiver, suivi de Pensées sous les nuages.
}

Paris. Gallimard. Coll. Poésie. 1994.178 pages.

The edition Jaccottet offers us here of the two collections originally appeared in 1977 and 1983 respectively, reveals a number of reworkings, smaller modifications and attachments, this especially being so for the first two parts of $A$ la lumiere $d$ 'hiver, those two "livres de deuil" as the poet terms them: Leçons, which goes back as far as 1966, and Chants d'en bas, written in 1973.

There is throughout the volume, as indeed Jaccottet's entire oeuvre, including his 1990 Cahier de verdure and the very recent Après beaucoup d'années (1994), an ethically homogeneous and psychologically unified quality which yet allows for greatly subtle swings of perception and impulse. The same is true, moreover, within the emotionally and conceptually mobile space of individual poems. Take, for example, "On peut nommer cela horreur, ordure...," from Leçons, where death is viscerally felt, yet distanced, as in «Parler» from Chants d'en bas, from the symbolic, necessarily unimmediate language conveying emotion and presence; where death is, equally, sensed to be, despite its affront, its disgrace, "simple comme la terre," where the questionning and unknowing, rife and plainly admitted everywhere in this poetry of l'ignorant, is "understood" either to join or to tear apart, and thus to do both, in simultaneity; where death may give off a "musty odour of old gods," yet, by the same token, set the mind racing, feet off the pedals, as to the divine mystery of all incarnation. Not dissimilarly, a collection like Pensées sous les nuages can begin rather serene, confident immersion in the ephemeral, its resistance to psychological turmoil and diffidence, its unexpected postulation of a light beyond light, an astonishment beyond the pleasures even of the late summer sun and the ripened vegetables in the garden - only to end with the sobriety of the "Le poete tardif..." And yet, even in this poem of fraying, distance, uncertainty and quasi-suicidal impulse, much lingers to erode the very erosions that threaten ontological integrity: a consciousness of beauty, of concrete, appreciable beauty; a hearing of the still present "music" of simple things, despite the blunting of expectancy and desire; a dogged persistance, a "rumbling advanc[ing] like a stream in 
January / with that rustling of leaves each time / a frightened bird flies off with a cry towards the clearing."

A moving, ever nuanced collection by one of France's - and Switzerland's - great poetic, and simply human, voices.

Michael Bishop

Dalhousie University 